\section{Environmental Effects in Areas with Intensive Pesticide Application: Risk for Exposure at State of Ceará, Northeast of Brasil}

\section{Silva, Adeildo Cabral ${ }^{1 *}$; Cabral, Nájila Rejanne Alencar Julião Cabral ${ }^{1}$ and Cabral, Gabriel Alencar Julião ${ }^{2}$}

${ }^{1}$ Department of Civil Engeenering, Federal Institute of Ceará, Fortaleza, Brazil

${ }^{2}$ Department of Analytical Chemistry and Physical Chemistry, Federal University of Ceará, Fortaleza, Brazil

\begin{abstract}
Indiscriminate use of pesticides, their exposure and disorders to human health are present discussion even today. This paper aims to study the situation of pesticide use and its environmental outcomes in the State of Ceará, Northeast Brazil. The research studied environmental effects and the risk of intensive use of pesticides in the 184 municipalities of the State of Ceará, from 2010 to 2017. The results show that the environmental issues of pesticide use are reveal of the current state status. The map of vulnerability of the State of Ceará designate 146 municipalities considered critical and 38 hold to be vulnerable concerning environmental and public health conditions. People are being exposed to a significant amount and variety of pesticides, of which health damage is becoming known, such as the intensive use of pesticides in Chapada do Apodi, where glyphosate has been found in the atmosphere (ranging from 0.31 to $2.93 \mathrm{\mu g} / \mathrm{m}^{3}$ ) in the municipality of Limoeiro do Norte/Ceará/Brazil. The results indicate that the inspection actions, from 2010 to 2017, were able to identify transgressions in the indiscriminate use of pesticides with high risks to the environment and human health. In the State of Ceará the use of pesticides in large quantities, in different crops and in most municipalities, has changed the environmental quality with potential water, soil and air contamination. The conflict
\end{abstract}

${ }^{*}$ Corresponding author: Silva AC, Department of Civil Engeenering, Federal Institute of Ceará, Fortaleza, Brazil, E-mail: cabral@ifce.edu.br

Citation: Silva AC, Cabral NRAJ, Cabral GAJ (2019) Environmental Effects in Areas with Intensive Pesticide Application: Risk for Exposure at State of Ceará, Northeast of Brasil. J Environ Sci Curr Res 2: 015.

Received: December 04, 2019; Accepted: December 12, 2019; Published: December 19, 2019

Copyright: (C) 2019 Silva AC, et al. This is an open-access article distributed under the terms of the Creative Commons Attribution License, which permits unrestricted use, distribution, and reproduction in any medium, provided the original author and source are credited. between increased pesticide use and environmental consequences was crucial for the government to establish, together with civil society, a joint action plan to curb indiscriminate use and non-compliance with relevant legislation. It is necessary to redefine public policies that guarantee safety and minimize the risks associated with the intensive use of pesticides.

Keywords: Brazil; Environmental effects; Pesticides; Risk; State of Ceará

\section{Introduction}

In the first half of the twentieth century, more than 200 chemicals were created for use in killing insects, weeds and other organisms, sold under different names and brands, warned Rachel Carson in her book Silent Spring. Carson stated, in a pioneering way, that the use of these substances, which she called biocides, embodies threats of disease and death, considering the potential of these substances to cause damage and contaminate the environment [1].

Some chemical substances (pesticides) are used as an excuse of increasing agriculture production and to combat insects and pests $[2,3]$. Pesticide is the term used to describe a range of chemicals utilized as insecticides, fungicides, herbicides and rodenticides [2,4]. A large number of pesticides classes (such as glyphosate, pyretroids) have been introduced in to agricultural practice, mainly in developing countries $[2,5]$. Some researchers, from various fields, lead to the assumption that agricultural spreading of glyphosate might bear health risks, including but not limited to carcinogenic, inflammatory and endocrine disruptive effects [6,7]. The general population may be exposed to glyphosate through dermal contact with consumer products, crops, foliage, or soils containing residues of this chemical. Glyphosate is present at low levels in a wide range food itemsbecause of the widespread usage $[3,8]$.

Disorders are relative with exposure. The health risk is dependent on the level of exposure. The more intensively a person are exposed, the longer the exposure period, consequently the higher the risk. Pesticide exposure has profound effects on human health, including increase risk of cancer, diabetes, genetic disorders, and neurotoxicity $[3,8]$. Some pesticides may interfere with normal hormonal function and thereby cause negative effects on the reproductive system [9].

Human exposure to some persistent organic pollutants can lead to cancer, endocrine disruption, neurobehavioral impairment, reproductive disorders, and birth defects [10].

Brazil, a developing country, is the most world consumer of pesticides since 2008, the United States of America (USA) are the second one $[11,12]$. Pesticides classes most sold, in Brazil, are herbicides $(62.2 \%)$, insecticides $(12.6 \%)$ and fungicides $(7.8 \%)$. Among the herbicides, glyphosate is the compound most sold in Brazil [13], that is about $48 \%$ of total $[13,14]$. 
Pesticides are persistent, mobiles and toxics for water, soil and air $[10,13,15]$. The occupational exposure in agriculture is likely to carry the most significant risk, followed by environmental exposures and risks to the consumers [8]. Widespread usage of pesticides might cause hazards to environment, human health and food contamination $[3,11,16]$.

Exposure to some pesticides leads to serious health consequences such as neurobehavioral and cognitive abnormalities, teratogenicity, endocrine modulation, immunotoxicity and compromised cognitive development, especially for infants and children, reproductive effects, spontaneous abortions, and fetal death [17].

Brazil has some laws about pesticides focused in its production, sell and proper use. Federal laws allow pesticides use as proper way and treat administrative, civic and penal responsibilities for any damage caused by pesticides $[18,19]$.

The State of Ceará, in Northest of Brazil, has specific law about pesticides, which concern proper use, sell, storage and control. The law also approaches some roles of different institutions regarding control, sell and final disposal of package residues of pesticides [20]. The State of Ceará is the tenth state in Brazilian ranking of pesticides consumes Martins, 2015. Between 2007 to 2012, the State of Ceará increase from $0.91 \mathrm{~kg} / \mathrm{ha}$ to $7.29 \mathrm{~kg} / \mathrm{ha}$ regarding pesticides consume, mainly because the agriculture practice, rice, corn and bean crops, and fruits farming. However, excessive pesticide use has increased the onset of morbidity and death, potentially correlated with exposure to toxic substances [16].

Indiscriminate use of pesticides, their exposure and disorders to human health are present discussion even today. Glyphosate is at the center of a public herbicide debate [8]. Glyphosate poisoning results in vomiting, diarrhea; severe cases develop cardiorespiratory toxicity, coma with gastrointestinal hemorrhage [2].

A pesticide company lost in US court a lawsuit filed by a terminally ill American whose cause of morbidity was exposure to glyphosate [21] even the United Nations Environmental Protection Agency - US EPA recently confirmed its position of "no public health risk when glyphosate is used under current label" and "glyphosate is not carcinogenic" [8].

This paper aims to study the situation of pesticide use and its environmental outcomes in the State of Ceará, Northeast Brazil, concerning the increasing consumption of pesticides in this state, from 2010 to 2017, its intensive application and the rise of cases of morbidity and deaths related to poisoning.

\section{Materials and Methods}

\section{Study of case}

The research study area is the State of Ceará. It is located in the Northeast of Brazil. The state of Ceará has 184 municipalities and consumes a large amount of pesticides in different crops, such as Abamex, Agritoate, Azodrim, Barrage, Cerconil PM, Fastac, Folisuper 600 BR, Gramoxone 200, Glyphosate, Lannate BR, Marshal 200 among others [22]. The figure 1 shows the location of Brazil and, specifically, of Ceará, in the Northeast.

The State of Ceará has $93 \%$ of its territory in the northeastern semi-arid region, which has characteristics of vulnerability to drought and precipitation irregularity. The land use is a significant factor of pressure on the environment in its territory. Different crops are an important human pressure, once a large and a range of pesticides are used on these crops, mainly in the municipalities of Ubajara, Tianguá, Varjota, Marco, Paraipaba, Morada Nova, Limoeiro do Norte, Mauriti e Quixeré. Those municipalities are part of the agriculture-irrigated perimeter of Chapada do Apodi.

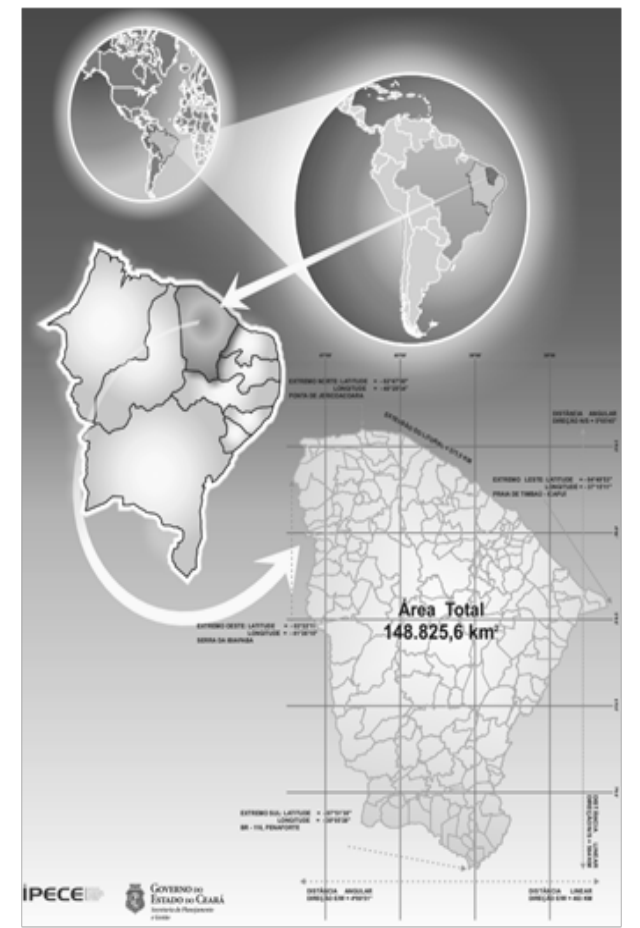

Figure 1: Location of Brazil and specifically Ceará, in the Northeast.

\section{Analysis method}

This study used quantitative and qualitative data from different sources. Data collection was done from secondary data, trough documentary research. The documents were provided by the State Secretariat of the Environment (SEMA), State Secretariat of Health (SESA) and by many researches reports, results of many researches under education centers. For each year (2010 to 2017), we made notes concerning pesticides control actions made by government of the State of Ceará and we correlation their effects in environmental and health.

To achieve the objective of the research, the analysis method follows Bardin [23] which allows content analysis, considering three steps, namely:

- pre-analysis: The organization of the material, in order to better understand the phenomenon and define what the researcher should focus his attention on;

- Analytical description: At this stage the gathered material is better deepened, being guided by the theoretical framework;

Referential interpretation: this is the analysis phase itself, where relationships with reality are established. 
Citation: Silva AC, Cabral NRAJ, Cabral GAJ (2019) Environmental Effects in Areas with Intensive Pesticide Application: Risk for Exposure at State of Ceará, Northeast of Brasil. J Environ Sci Curr Res 2: 015.

Content analysis is qualitative method, based on data collection. Qualitative research provides better insight and understanding of the problem, especially in situations of uncertainty. Qualitative research "is based on small and unrepresentative samples and data are not statistically analyzed" [24].

The object of study is the State of Ceará, considering the integrated actions of pesticide inspection that took place from 2010 to 2017.

\section{Results and Discussion}

\section{Agricultural crops in the State of Ceará}

The agricultural sector plays a relevant role for the State of Ceará, mainly for production of food. Agricultural crops are one of economic activities that improvement of the population's quality of life, specifically for generating of jobs and income. The agricultural sector reduces the rural population migration for urban centers. The State of Ceará is a producer of beans, corn, rice, herbaceous and arboreal cotton, cashews, sugar cane, cassava, castor, tomato, banana, coconut, melon, watermelon, mango and pineapple, among others. Some authors affirm although indiscriminate use of pesticides is a problem in all municipalities of the State of Ceará, it is presumed to be more pronounced in local governments next to Chapada do Apodi, eastern portion of the State of Ceará, on the border with State of Rio Grande do Norte. Geographically it comprises the municipalities of Limoeiro do Norte, Quixeré, Tabuleiro do Norte and Alto Santo, in Ceará territory.Chapada do Apodi is a producer of rice, corn, beans and tropical fruits such as mango, banana, "acerola", melon and watermelon, which are exported to other Brazilian states and many countries [22].

The formulated products in the agriculture and gardening market are labeled for use on fruits, vegetables and field crops, as well as on aquatic and terrestrial crops $[25,26]$. That is the case of pesticides used in agricultural crops in the State of Ceará.

\section{Environmental effects and the risk of pesticides intensive use at State of Ceará}

Since 1995, the Environment Superintendence of State of Ceará (SEMACE) develops the Program for Control and Inspection of Pesticides concerning the indiscriminate use of pesticides. The results of this monitoring showed that State of Ceará consumes a large amount of pesticides, such as municipalities of Ubajara, Tianguá, Varjota, Marco, Paraipaba, Morada Nova, Limoeiro do Norte, Mauriti and Quixeré. Among the pesticides used are Abamex, Agritoate, Azodrim, Barrage, Cerconil PM, Fastac, Folisuper 600 BR, Gramoxone 200, Glyphosate, Lannate BR, Marshal 200 and others [22]. Glyphosate is a phosphate herbicide for weed control, which is extensively used and become the most commercialized herbicide in the world [27].

From 2007 to 2010, the foundation of meteorology and water resources in Ceará (Funceme) studied and evaluated the presence of pesticides in surface and underground water resources, as well as the drainage waters of the influence area of the Morada Nova irrigation perimeter, in Ceará. This research focused on the waters used for domestic supply regarding risk of human health [28].

Pesticides used in agricultural crops in someIrrigated Perimeters, such as Morada Nova Projectand in Jaguaribe-Apodi Project (Table 1) may be a health risk. It is common practice to mix different pesticides. Farmers reported health problems after the application of pesticides, such as dizziness, burning eyes, fainting, vomiting, pallor, itching, among others. The worst, final destination of pesticides empty packaging is improperly performed on the farm itself [28].

\begin{tabular}{|c|c|}
\hline Morada Nova Project & Jaguaribe-Apodi Project \\
\hline $\begin{array}{l}\text { Abamex; Acephate; Actara 250 } \\
\text { WG; Agritoate 400; Azodrim; } \\
\text { Barrage; Cercobin 500 SC; Cerconil } \\
\text { PM; Decis } 25 \text { EC; Fastac 100; } \\
\text { Folisuper 600 BR; Glyphhosate; } \\
\text { Gramoxone 200; Juno; Karate } \\
\text { 50 CE; Lannate BR; Madaldrin; } \\
\text { Manzate WG; Marshal 200 SC; } \\
\text { Mospilan; Native; Opera; Propanyl; } \\
\text { Stron; Tamaron BR; Tordon; Ver- } \\
\text { timec 18 EC. }\end{array}$ & $\begin{array}{l}\text { Abamectin; Acephate; Acetamiprido; Atrazine; } \\
\text { Azoxystrobin; Carbosulfan; CartapCypermethrin; } \\
\text { Ketethim; Chlorotalonil; Chlorpyrifos; 2.4 D; Di- } \\
\text { phenoconazole; Endosulfan; Sphenvarelate; Spi- } \\
\text { nosad; Fenitrothion; Fenpropatrin; Glyphhosate; } \\
\text { Imidacloprid; Cyhalothrin lambda; Lufenuron; } \\
\text { Mancozeb; Mesotrione; Metamidophos; Me- } \\
\text { tolachlor; Methomyl; Nicosulfuron; Paraquat; } \\
\text { Methylparation; Piraclostrobin; Pyriproxyfen; } \\
\text { Propiconazole; Teflubenzuron; Thiamethoxam; } \\
\text { Triazophos; Trifloxystrobin. }\end{array}$ \\
\hline
\end{tabular}

Table 1: Pesticides used in two Irrigated Perimeters at State of Ceará: Morada Nova Project and Jaguaribe-Apodi Project Fonte: Milhome et al. [29]; Almeida. [28]; Funceme [30].

The most farmers in Morada Nova Project systematically used pesticides (herbicides, insecticides and fungicides) on the property as a pest control agricultural practice [28].

Aware of the potential contamination of soil, air and water, in 2010 the State of Ceará created Plan of Joint Action on Pesticides, to combating the indiscriminate use of pesticides [16]. Since 2010, enforcement actions have intensified, considering the areas of criticality and vulnerability of pesticide contamination identified by Carvalho and Lima Júnior, [22].

The map of vulnerability of the 184 municipalities of the State of Ceará (Figure 2) designate 146 municipalities considered critical and 38 hold to be vulnerable concerning environmental and public health conditions. We may say it is very worrisome scenario, since all territory stands out for intensive use of pesticides for agribusiness focused on the great productivity of fruits, corn, beans and sugar cane.

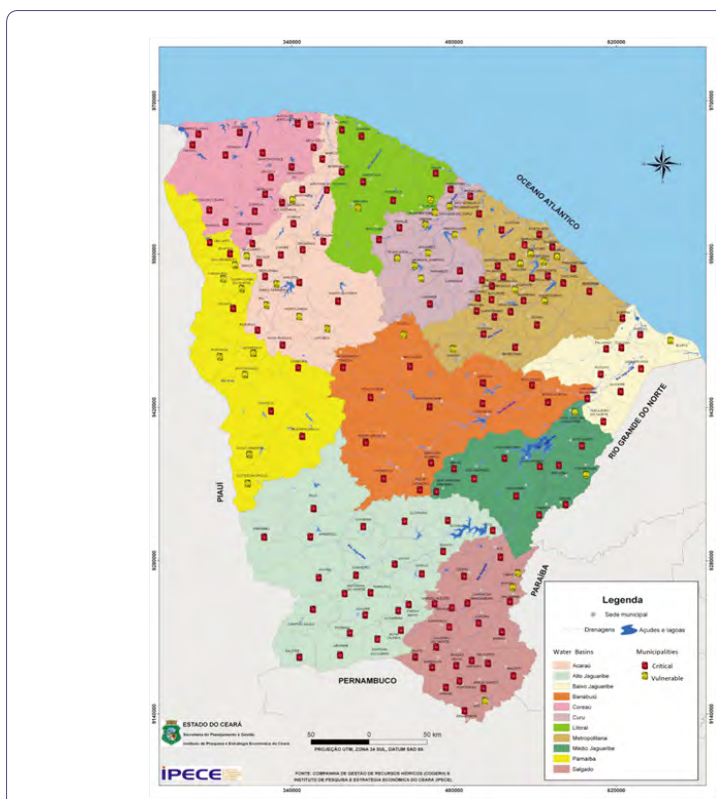

Figure 2: Map of vulnerability of State of Ceará concerning use of pesticides. Source: Carvalho and Lima Júnior, [22]. 
This map reinforces the urgent need for public policies definition focused for disciplining use of pesticides in the state of Ceará. People are being exposed to a significant amount and variety of pesticides, and the risk of intensive use of pesticides start to be known.

Changes on water, soil and air environmental quality: Risk of contamination: A recent study identified glyphosate in the atmosphere of the municipality of Limoeiro do Norte, in all samples collected in rural areas, including agricultural and non-agricultural areas, ranging from 0.313 to $2.939 \mu \mathrm{g} / \mathrm{m}^{3}$ [14]. The amount found in the municipality exceeds ten of thousands of times what the literature of other countries recommends as admissible. Therefore, this finding can contribute significantly to changes in air quality and cause damage to the health of the population. These observed values can be worrisome for the population of the municipality of Limoeiro do Norte, since atmospheric air moves from the Chapada do Apodi (rural zone) to the urban zone through the drift of the winds [31].

There is environmental contamination in the surface waters of the Jaguaribe-Apodi Project, as research conducted in the region collected 24 samples from different abstraction points and in all, at least three active ingredients were detected, including Abamectin and the chlorpyrifos [32]. Another recent study observed the birth of children with congenital malformations, which may be associated with environmental and occupational exposure of the family nucleus to pesticides [33].

Governmental reports of State of Ceará, resulting from joint action inspection actions carried out from 2010 to 2017, show violations of rural properties in different municipalities, which may compromise the environment and significantly imply the loss of environmental quality. The inappropriate disposal of empty pesticide packaging is one of these violations. This inadequate way of disposal may cause contamination of soil itself and surface waters and consequently reaching the subsoil and groundwater.

Brazilian federal Law force farmers to wash three times each empty packaging for later send to an appropriate collect site. In State of Ceará, we have two appropriate collect site in two municipalities Quixeré and Ubajara. In of the field control actions, in 2013, occurred in municipalities of Viçosa do Ceará, Tianguá, Ubajara, Ibiapina, São Benedito and Guaraciaba do Norte, 9 from 23 rural farms did not send their empty packaging for adequate disposal [16].

In august 2017, another field control actions took place in Chapada do Apodi. There were 17 from 24 viollations in farms in the municpalities of Limoeiro do norte, Morada Nova, Quixeré, Russas and Tabuleiro do Norte, concerning empty packaging inappropriate disposal [16].

Researches about the effects of exposure to pesticides on the health of the population in the municipalities of Limoeiro do Norte, Quixeré, and Russas observed a trend of a statistically significant increase in rates of hospitalizations for neoplasias $[11,31]$.

There are many environmental outcomes due intensive use of pesticides at State of Ceará. People are exposed to quantitative of pesticide, because agribusiness. We have not an air, water and soil constant monitoring process through time, made by government. However, health damages start to be known through researches. Pesticides may cause several diseases, including death. The case reported by
Charpentrant [21], in the USA, may be a warning to economic agents (pesticide companies) that is important to inform people about the dangerousness of these products and the diseases they can cause, including cancer. It may also mean a warning to economic agents (farmers) that there is a price to pay, whose decision to use pesticide necessarily will be linked to civil, criminal and administrative liability or, worse, will be associated with probability of severe illness and death.

\section{Conclusion}

In Brazil, including in the State of Ceará, Even though there are laws that address the proper use of pesticides, the scenario in Ceará is likely to contaminate water, air and soil. Data from many researches relates cause and effect to human health, so we concluded that in fact pesticides are potentially responsible for severe illness upon human exposure to these contaminants.

The conflict between increased pesticide use and environmental (including human health) effects was relevant for the government to establish, together with civil society, a joint action plan to curb indiscriminate use and non-compliance with legislation.

Despite the finding of certain advances, in Ceará, from 2010 to 2017, through inspection, control and intervention actions to support rural farmers and municipalities, there is still much to plan and achieve. Although human exposure is almost inevitable, the challenge is to reduce risks of exposure and produced into redefinition of public policies that minimize the uncertainties of intensive pesticide use.

\section{Acknowledgement}

We thank Technological and Environmental Management Postgraduate Programme, mainly PRPI/ARINTER n $01 / 2018$. The authors thank Laboratory of Renewable Energy and Environmental Comfort (LERCA)/IFCE.

\section{References}

1. Carson R (1969) Primavera Silenciosa. Tradução de Raul de Polillo, $2^{\mathrm{a}}$ edição. São Paulo: Edições Melhoramentos.

2. Eddleston M (2015) Pesticides. Medicine 44: 193-196.

3. Cabrera LY (2017) Pesticides: A case domain for environmental neuroethics. Cambridge Quarterly of Healthcare Ethics 26: 602-615.

4. WHO (2010)International Programme on Chemical Safety: The WHO recommended classification of pesticides by hazard.WHO, Geneva, Switzerland.

5. Samare M, Samareh AN, Safari S, Zaree R, Moghadam D, et al. (2020) A survey of the secondary exposure to organophosphate and organochloride pesticides and the impact of preventive factors in female villagers. Chemosphere 240: 124887 .

6. Mesnage R, Defarge N, Spiroux de Vendômois J, Séralini GE (2015) Potential toxic effects of glyphosate and its commercial formulations below regulatory limits. Food Chem Toxicol 84: 133-153.

7. Szepanowski F, Kleinschnitz C, Stettner M (2019) Glyphosate-based herbicide: A risk factor for demyelinating conditions of the peripheral nervous system? Neural Regen Res 14: 2079-2080.

8. Vainio H (2019) Public health and evidence-informed policy-making: The case of a commonly used herbicide. Scand J Work Environ Health 5: 3851. 
Citation: Silva AC, Cabral NRAJ, Cabral GAJ (2019) Environmental Effects in Areas with Intensive Pesticide Application: Risk for Exposure at State of Ceará, Northeast of Brasil. J Environ Sci Curr Res 2: 015.

9. Silvia SC, Magnarelli G, Rovedatti MG (2019) Evaluation of endocrine disruption and gestational disorders in women residing in areas with intensive pesticide application: An exploratory study. Environ Toxicol Pharmacol 73: 103280 .

10. Hu Z, Li J, Li B, Zhang Z (2019) Annual changes in concentrations and health risks of PCDD/Fs, DL-PCBs and organochlorine pesticides in ambient air based on the Global Monitoring Plan in São Paulo. EnvironPollut 255: 113310.

11. Rigotto MR, Silva AMC, Ferreira MJ, Rosa IF, Aguiar ACP (2013) Tendências de agravos crônicos àsaúde associados aos agrotóxicos em região de fruticultura no Ceará, Brasil. Revista Brasileira de Epidemiologia 16: 763-773.

12. Ferreira MJM, Viana Júnior MM (2016) A expansão do agronegócio no semiárido cearense e suas implicações para a saúde, o trabalho e o ambiente. Interface: comunicação, saúde, educação 20: 646-660.

13. Instituto Brasileiro de Geografia e Estatística (2015) Indicadores de Desenvolvimento Sustentável. Instituto Brasileiro de Geografia e Estatística, Rio de Janeiro, Brazil.

14. Sousa MGF (2015) Avaliação do herbicida glifosato presente na atmosfera: estudo de caso município de Limoeiro do Norte-CE.[Mestrado em Tecnologia e Gestão Ambiental].Fortaleza: Instituto Federal do Ceará

15. Annibelli MB (2004) Impacto dos agrotóxicos sobre o meio ambiente no Estado do Paraná - Brasil. Polígonos Revista de Geografia14: 169-181.

16. Queiroz DB (2018) Análise das ações integradas de fiscalização no combate aso uso indiscriminado de agrotóxico no Estado do Ceará. Trabalho de Conclusão de Curso de Tecnologia em Saneamento Ambiental. Fortaleza: Instituto Federal do Ceará, campus Fortaleza.

17. Derbalah Aly, Chidya Russel, Jadoon Waqar, Sakugawa Hiroshi (2019) Temporal trends in organophosphorus pesticides use and concentrations in river water in Japan, and risk assessment. Journal of Environmental Sciences 79: 135-152.

18. Brasil (1989) Lei Federal no 7.802, de 11 de julho de 1989, dispõe sobre a pesquisa, a experimentação, a produção, a embalagem e rotulagem, o transporte, o armazenamento, a comercialização, a propaganda comercial, a utilização, a importação, a exportação, o destino final dos resíduos e embalagens, o registro, a classificação, o controle, a inspeção e a fiscalização de agrotóxicos, seus componentes e afins, e dá outras providências. Brasília: DOU.

19. Brasil. 1989. Decreto Federal no 4.074, de 4 de janeiro de 2002,regulamenta a Lei $\mathrm{n}^{\circ} 7.802$, de 11 de julho de 1989 , que dispõe sobre a pesquisa, a experimentação, a produção, a embalagem e rotulagem, o transporte, 0 armazenamento, a comercialização, a propaganda comercial, a utilização, a importação, a exportação, o destino final dos resíduos e embalagens, o registro, a classificação, o controle, a inspeção e a fiscalização de agrotóxicos, seus componentes e afins, e dá outras providências. Brasília: DOU.
20. Ceará 1993. Lei Estadual n ${ }^{\circ} 12.228$, de 9 de dezembro de 1993, dispõe sobre o uso, a produção, o consumo, o comércio e o armazenamento dos agrotóxicos, seus componentes e afins bem como sobre a fiscalização do uso de consumo do comércio, do armazenamento e do transporte interno desses produtos. Fortaleza: DOE.

21. Charpentrat, J. 2018. Começa nos EUA primeiro julgamento por herbicida de glifosato da Monsanto. Disponível em https://www1.folha.uol.com.br (Acesso em 09jul2018).

22. Carvalho AM, Lima Júnior AA (2010) Plano Estadual de Ação Conjunta em Agrotóxicos do Estado do Ceará. Fortaleza: Conselho de Políticas e Gestão do Meio Ambiente.

23. Bardin L (2006) Análise de Conteúdo. Lisboa: Edições 70.

24. Malhotra NK (2006) Pesquisa de marketing: Uma orientação. Bookman.

25. Stephenson CL, Harris CA(2016) An assessment of dietary exposure to glyphosate using refined deterministic and probabilistic methods. Food Chem Toxicol 95: 28-41.

26. Ledoux ML, Hettiarachchy Navam, Yu Xiaofan, Howard Luke, Sun-Ok Lee (2020) Penetration of glyphosate into the food supply and the incidental impact on the honey supply and bees. Food Control109: 106859.

27. Jiang Yuxuan, Zhong Wen, Yan Wei, Yan Li (2019) Arsenic mobilization from soils in the presence of herbicides. Journal of Environmental Sciences 85: 66-73.

28. Almeida MMM (2010) Impactos Ambientais do Uso de Agroquímicos e Possibilidades de Reúso das Águas de Drenagem. Fortaleza: Funceme.

29. Milhome MAL, Sousa DOB, Lima FABF, Nascimento RF (2009) Assessment of surface and groundwater potential contamination by agricultural pesticides applied in the region of BaixoJaguaribe, CE, Brazil. Revista Engenharia Sanitária e Ambiental 4: 363-372.

30. Funceme- Fundação Cearense de Meteorologia e dos Recursos Hídricos. 2010. Estudo da Qualidade das águas Superficiais e Subterrâneas do perímetro de Irrigação de Morada Nova, Ceará. Impactos Ambientais do Uso de Agroquímicos e Possibilidades de Reúso das águas de drenagem. Fortaleza: Funceme.

31. de F Sousa MG, da Silva AC, Dos Santos Araújo R, Rigotto RM(2019) Evaluation of the atmospheric contamination level for the use of herbicide glyphosatein the northeast of Brazil. Environ Monit Assess 191:604.

32. Ferreira MJM, Viana Júnior MM, Pontes AGV, Rigotto RM, Gadelha ADG (2016) Gestão e uso dos recursos hídricos e a expansão do agronegócio: água para quê e para quem? Ciência e Saúde Coletiva 21: 743-752.

33. Aguiar ACP (2017) Más-formações congênitas, puberdade precoce e agrotóxicos: Uma herança malditado agronegócio para a Chapada do Apodi (CE). Federal University of Ceará (Reitoria, Universidade Federal do Ceará), Fortaleza, Brazil. 


\section{di}

Journal of Anesthesia \& Clinical Care

Journal of Addiction \& Addictive Disorders

Advances in Microbiology Research

Advances in Industrial Biotechnology

Journal of Agronomy \& Agricultural Science

Journal of AIDS Clinical Research \& STDs

Journal of Alcoholism, Drug Abuse \& Substance Dependence

Journal of Allergy Disorders \& Therapy

Journal of Alternative, Complementary \& Integrative Medicine

Journal of Alzheimer's \& Neurodegenerative Diseases

Journal of Angiology \& Vascular Surgery

Journal of Animal Research \& Veterinary Science

Archives of Zoological Studies

Archives of Urology

Journal of Atmospheric \& Earth-Sciences

Journal of Aquaculture \& Fisheries

Journal of Biotech Research \& Biochemistry

Journal of Brain \& Neuroscience Research

Journal of Cancer Biology \& Treatment

Journal of Cardiology: Study \& Research

Journal of Cell Biology \& Cell Metabolism

Journal of Clinical Dermatology \& Therapy

Journal of Clinical Immunology \& Immunotherapy

Journal of Clinical Studies \& Medical Case Reports

Journal of Community Medicine \& Public Health Care

Current Trends: Medical \& Biological Engineering

Journal of Cytology \& Tissue Biology

Journal of Dentistry: Oral Health \& Cosmesis

Journal of Diabetes \& Metabolic Disorders

Journal of Dairy Research \& Technology

Journal of Emergency Medicine Trauma \& Surgical Care

Journal of Environmental Science: Current Research

Journal of Food Science \& Nutrition

Journal of Forensic, Legal \& Investigative Sciences

Journal of Gastroenterology \& Hepatology Research

Journal of Gerontology \& Geriatric Medicine
Journal of Genetics \& Genomic Sciences

Journal of Hematology, Blood Transfusion \& Disorders

Journal of Human Endocrinology

Journal of Hospice \& Palliative Medical Care

Journal of Internal Medicine \& Primary Healthcare

Journal of Infectious \& Non Infectious Diseases

Journal of Light \& Laser: Current Trends

Journal of Modern Chemical Sciences

Journal of Medicine: Study \& Research

Journal of Nanotechnology: Nanomedicine \& Nanobiotechnology

Journal of Neonatology \& Clinical Pediatrics

Journal of Nephrology \& Renal Therapy

Journal of Non Invasive Vascular Investigation

Journal of Nuclear Medicine, Radiology \& Radiation Therapy

Journal of Obesity \& Weight Loss

Journal of Orthopedic Research \& Physiotherapy

Journal of Otolaryngology, Head \& Neck Surgery

Journal of Protein Research \& Bioinformatics

Journal of Pathology Clinical \& Medical Research

Journal of Pharmacology, Pharmaceutics \& Pharmacovigilance

Journal of Physical Medicine, Rehabilitation \& Disabilities

Journal of Plant Science: Current Research

Journal of Psychiatry, Depression \& Anxiety

Journal of Pulmonary Medicine \& Respiratory Research

Journal of Practical \& Professional Nursing

Journal of Reproductive Medicine, Gynaecology \& Obstetrics

Journal of Stem Cells Research, Development \& Therapy

Journal of Surgery: Current Trends \& Innovations

Journal of Toxicology: Current Research

Journal of Translational Science and Research

Trends in Anatomy \& Physiology

Journal of Vaccines Research \& Vaccination

Journal of Virology \& Antivirals

Archives of Surgery and Surgical Education

Sports Medicine and Injury Care Journal

International Journal of Case Reports and Therapeutic Studies

Submit Your Manuscript: http://www.heraldopenaccess.us/Online-Submission.php 